\begin{tabular}{cc|c}
\hline Tar. Bil. Der. & Journal of Agricultural Sciences \\
& $\begin{array}{c}\text { Dergi web sayfası: } \\
\text { www.agri.ankara.edu.tr/dergi }\end{array}$ & Journal homepage: \\
& www.agri.ankara.edu.tr/journal
\end{tabular}

\title{
Chlorella vulgaris Üretimi ve Sera Organik Domates Yetiştiriciliğinde Biyogübre Olarak Kullanımının Etkileri
}

\author{
Sena ÖZDEMIIR ${ }^{\text {, }}$, Atakan SUKATAR ${ }^{\text {a }}$, Gölgen Bahar ÖZTEKİN ${ }^{b}$ \\ ${ }^{a}$ Ege Üniversitesi, Fen Fakültesi, Biyoloji Bölümü, 35100, İzmir, TÜRKIYE

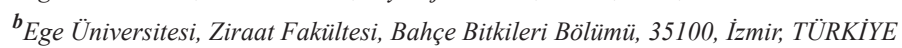

\section{ESER BILGISII}

Araştırma Makalesi

DOI: 10.1501/Tarimbil_0000001418

Sorumlu Yazar: Atakan SUKATAR, E-posta: atakan.sukatar@ege.edu.tr, Tel: +90 (232) 3112447

Geliş Tarihi: 26 Şubat 2015, Düzeltmelerin Gelişi: 01 Eylül 2015, Kabul: 04 Eylül 2015

\begin{abstract}
ÖZET
Chlorella vulgaris mikroalginin üretilmesi ve biyogübre olarak kullanımının domates bitkisi üzerinde bitki gelişimi, verim ve meyve kalitesine etkilerinin araştırılması amacıyla yürütülen çalışmada, C. vulgaris tübüler fotobiyoreaktörde üretilmiş ve serada organik domates (cv. Şimşek) yetiştiriciliğinde 3 farklı formda [toprağa toz alg uygulaması (2.5 g fide $\left.^{-1}\right)$, toprağa sıvı alg uygulaması ( $\left.250 \mathrm{~mL}_{\text {fide }}{ }^{-1}\right)$, yaprağa sıvı alg spreylenmesi] denemeye alınmıștır. Alg uygulanmayan bitkiler kontrol grubunu oluşturmuştur. Deneme tesadüf parseli deneme desenine uygun olarak kurulmuş; üretim 2014 yılı Mart-Haziran aylarında gerçekleştirilmiştir. Elde edilen sonuçlar C. vulgaris' in biyogübre olarak kullanımının bitki gelişimi, verim ve bazı meyve kalite parametrelerini (kuru ağırlık, toplam suda çözünür kuru madde, titre edilebilir asit ve vitamin C) artırdığını; kullanılan uygulamalar içerisinde özellikle toprağa kuru alg uygulamasının daha iyi sonuçlar verdiğini; doğa dostu bir gübre olarak C. vulgaris'in organik tarımda kullanılabileceğini göstermiştir.
\end{abstract}

Anahtar Kelimeler: Mikroalg; Organik tarım; Bitki gelişimi; Verim; Kalite

\section{Production of Chlorella vulgaris and Its Effects on Plant Growth, Yield and Fruit Quality of Organic Tomato Grown in Greenhouse as Biofertilizer}

\author{
ARTICLE INFO \\ Research Article \\ Corresponding Author: Atakan SUKATAR, E-mail: atakan.sukatar@ege.edu.tr, Tel: +90 (232) 3112447 \\ Received: 26 February 2015, Received in Revised Form: 01 September 2015, Accepted: 04 September 2015
}

\begin{abstract}
This study was carried out to examine the production of Chlorella vulgaris and its effects on growth, yield, and fruit quality of organically grown tomato production in greenhouses, C. vulgaris was cultured in a tubular photobioreactor system and was used in three different forms [dry algae application to soil $\left(2.5 \mathrm{~g}\right.$ seedling $\left.{ }^{-1}\right)$, liquid algae application to soil $\left(250 \mathrm{~mL}_{\text {seedling }}^{-1}\right)$, foliar spray] used as biofertilizer on tomato production (cv. Simsek). Plants with no algae application were used as control. The experiment was designed according to randomized parcel and production was
\end{abstract}


performed between March and June of 2014. Obtained results showed that using C. vulgaris as a biofertilizer increased plant growth, yield and some fruit quality (dry weight, total soluble solids, titratable acidity and vitamin C); among the used treatments, applications to soil -especially dry algae- showed better performance; C. vulgaris may be used as a nature-friendly fertilizer in organic farming.

Keywords: Microalgae; Organic agriculture; Planth growth; Yield; Quality

(C) Ankara Üniversitesi Ziraat Fakültesi

\section{Giris}

Dünyada artan nüfus ile birlikte tarım yapılabilecek arazilerin de giderek azalmasıyla daha fazla gida üretimine ihtiyaç duyulmuş ve birim alandan daha fazla ürün elde etmek zorunda kalınmıştır. Bu amaçla da kimyasal gübre kullanımı oldukça artmıştır. Tarım alanlarındaki bu yoğun kimyasal kullanımı, verim ve üretimi artırmış fakat sürdürülebilir toprak verimliliği ile birlikte doğal dengenin bozularak tehlikeye girmesine sebep olmuştur. Sonuçta da başta gelir düzeyi yüksek ülkelerde olmak üzere birçok ülkede üretici ve tüketiciler örgütlenerek insanlarda toksik etki yaratmayan ve doğayı tahrip etmeyen yöntemlerle üretilen tarımsal ürünleri tercih etmeye başlamışlardır. Bu amaçla insan ve çevreye dost üretim sistemlerini içeren, kimyasal gübre ve ilaçların kullanımını yasaklayan, organik gübreleme ile ekim nöbeti uygulamayı, parazit ve predatörler gibi doğal kaynaklardan yararlanmayı tavsiye eden ve üretimde ürünün kalitesinin yükselmesini amaçlayan bir üretim şekli olan "organik tarım" ortaya konmuştur (Hekimoğlu \& Altındeğer 2006).

Organik tarımda sınırlı olan gübreler konusunda yapılan alternatif arayışlar, alglerin gübre olarak kullanılabileceğini göstermiştir (Abetz 1980; Şimşek 1995). İlk defa Norveç, İrlanda, Fransa ve Amerika gibi denize kıyısı olan ve denizsel alglerin bol bulunduğu ülkelerde mevcut algleri değerlendirmek için bu alglerden yararlanma yolları aranmış ve verimsiz toprakların değerlendirilmesinde alglerin gübre olarak kullanımıyla ilgili ilk adımlar atılmıştır (Whapham et al 1994; Güner \& Aysel 1996; Kumbul 2000). Şimdiye kadar yapılan biyogübre çalışmalarında ağırlıklı olarak denizsel algler (kelpler) ve Cyanophyta üyesi filamentöz algler kullanılmış, mikroalglerin kullanımı ise geri planda kalmıştır (Sivasankari et al 2006; Selvam \& Sivakumar 2014) .
Biyoteknolojik uygulanabilirliği en yüksek olan mikroalg türlerinden $C$. vulgaris geniş çapta ticarileştirilmiş olup, insanlar tarafından gıda takviyesi ve hayvanlar için yem katkı maddesi olarak kullanılmaktadır. Chlorophyta üyesi olan bu alg, \% 42-58 gibi yüksek protein içeriğine sahip olması nedeniyle alternatif protein kaynağ 1 olarak görülmekte ve birçok ülke tarafindan çeşitli amaçlar için kültüre alınmaktadır (Safi et al 2014). Tarımda genellikle azot kaynağı olarak kullanılan kimyasal gübrelerin yerine, $C$. vulgaris gibi yüksek protein içeriğine sahip olan alglerin kullanımı, daha ucuz ve çevre sağlığına zarar vermeyen bir uygulama olacaktır. Ancak gerek dünyada ve gerekse ülkemizde mikroalglerin biyogübre olarak kullanılması ile ilgili yapılan araştırmalar sınırlı sayıda ve dar kapsamlıdır.

Yürütülen bu çalışmada, yeşil alglerden zengin protein içeriğine sahip C. vulgaris'in tübüler fotobiyoreaktörle geniş ölçekli üretimi yapılmış ve elde edilen biyogübre ülkemizin birçok kesiminde yetiştirilen ve büyük bir tarımsal öneme sahip domates bitkisinde denenmiş, biyogübre uygulamasının; bitki gelişimi, verim ve meyve kalite parametreleri üzerine etkileri incelenmiştir. Böylelikle $C$. vulgaris'in özellikle organik tarımda kimyasal gübrelere alternatif olarak kullanılabilecek bir biyogübre olup olmayacağı araştırılmıştır.

\section{Materyal ve Yöntem}

Ekim 2013-Temmuz 2014 döneminde yürütülen bu araştırma, (I) C. vulgaris mikro alginin üretilmesi ve (II) elde edilen mikroalgin serada organik domates yetiştiriciliğinde biyogübre olarak kullanılması şeklinde iki aşamada gerçekleştirilmiştir. 


\subsection{Chlorella vulgaris mikroalginin üretilmesi}

Kullanılan C. vulgaris türü Ege Üniversitesi (E.Ü.), Mikroalg Kültür Koleksiyonu'ndan (EGE-MACC) temin edilmiş ve E.Ü. Fen Fakültesi, Biyoloji Bölümü'nde tübüler fotobiyoreaktörde, Bold Basal Medium (BBM) (pH: 6.8) kültürü kullanılarak üretilmiştir (Guillard 1973; Sukatar 2002). Üretimin ilk aşaması olan aşı kültüründe mikroalgler BBM ortamı içeren $70 \mathrm{~mL}$ tüp içerisinde 1 hafta inkübe edilmiş, süre sonunda 15 günlük aralıklarla 250 $\mathrm{mL}, 500 \mathrm{~mL}$ ve 5 L'lik hacimlere $\left(25^{\circ} \mathrm{C}, 12\right.$ saat karanlık-12 saat aydınlık, $20 \mu \mathrm{mol}$ foton $\mathrm{m}^{-2} \mathrm{~s}^{-1}$ 1şık şiddeti altında) aktarılmıştır. Başlangıçta elle çalkalama şeklinde yapılan alg karıştırma işlemi, hacim büyüdükçe besleme sistemine hava üflemesi ile gerçekleştirilmiştir. 150 L'lik tübüler fotobiyoreaktöre aktarıma uygun olup olmadığını belirlemek için de 2 gün ara ile Neubauer lamı (Marienfield, $0.0025 \mathrm{~m}^{2}$ ) kullanılarak mikroskopta hücre sayımı yapılmıştır. Kültür hacminin artırılması sırasında trinokuler mikroskoba bağlı kamera (CX31RTSF-5, Olympus) ile hücre boyutu, rengi ve şekline bakılmış; alglerin hücre morfolojileri incelenmiştir.

C. vulgaris'in büyük çaplı üretiminde toplam üretim kapasitesi $150 \mathrm{~L}$ olan, ortasında fotoperiyodu ayarlanabilir fotosentez lambası bulunan, her biri $195 \mathrm{~cm}$ uzunluk ve $5 \mathrm{~cm}$ çapa sahip yatay olarak yerleştirilmiş 20 adet akrilik borudan ve 100 L'lik toplama tankından oluşan tübüler fotobiyoreaktör

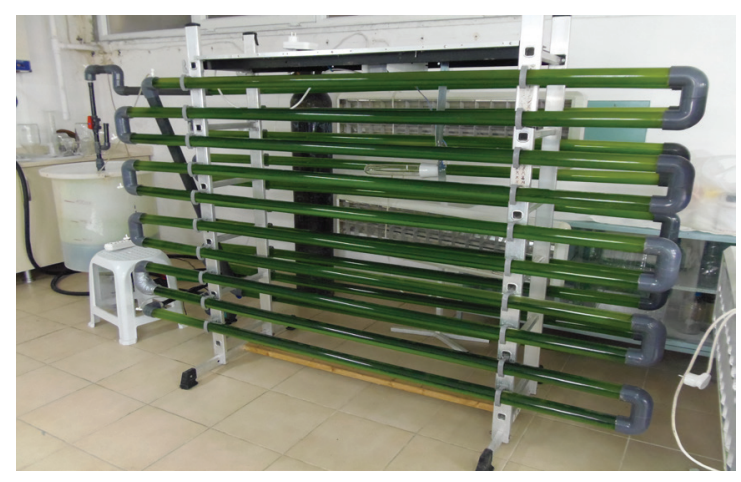

Şekil 1- Tübüler fotobiyoreaktörün genel görünümü Figure 1-General view of tubuler photobioreactor kullanılmıştır (Şekil 1). Toplama tankındaki alg kültürünün sirkülasyonunu sağlamak için pompa (New Jet 3000 model, 55W, 3000 L kapasiteli, max. su yüksekliği: $2.90 \mathrm{~m})$ kullanılmıştır. Fotobiyoreaktörde sirküle olan kültürün akış hızı saniyede $20 \mathrm{~cm}$ yer değiştirme şeklinde olmuştur.

Tübüler fotobiyoreaktörde üretim arka arkaya 2 tekrarlı olarak gerçekleştirilmiştir. Her tekrarda, toplama tank1 ve biyoreaktörün sterilizasyonu çeşme suyu ve ardından \% 16'lık sodyum hipoklorit ilaveli su ile sağlanmıştır. Her tekrarda 150 L'lik biyoreaktöre 5 L'lik C. vulgaris kültürü aşılanmış ve üretim 12:12 saat (aydınlık:karanlık) döngüsünde, 25 gün sürdürülmüştür. Her iki üretimde de toplama tankından günlük örnekler alınarak $\mathrm{pH}$ ve sıcaklık ölçümleri yapılmış, mikroskop altında hücre sayısı, şekil ve yapısı belirlenmiştir. Üretim süreci sonunda sistem içerisindeki 100 L'lik C. vulgaris kültürü şişelere aktarılmış ve $-20^{\circ} \mathrm{C}$ 'de saklanmıştır (Cirik \& Gökpınar 1993).

Elde edilen sıvı kültür, büyük ölçekli separatörde (CTC-1-06-107, Westfalia GmbH) 10000 rpm'de santrifüjlenmiştir. Separatörden alınan alg pastası $45{ }^{\circ} \mathrm{C}$ sıcaklığa ayarlı etüvde kurutumuş, kuru haldeki C. vulgaris sıvı azot ile havanda 10 dakika parçalanmıştır (Zheng et al 2011). C. vulgaris kuru ekstraktının toplam $\mathrm{N}$ miktarı, modifiye Kjeldahl Metodu ile; diğer elementlerin $(\mathrm{K}, \mathrm{Ca}$, $\mathrm{Mg}$ ) analizleri ise nitrik:perklorik asit karışımında yaş yakılmış örneklerle yapılmıştır. Potasyum (K) alev fotometresinde; $\mathrm{Ca}$ ve $\mathrm{Mg}$ ise absorbsiyon spektrofotometresinde tayin edilmiştir (Kacar 1972).

\subsection{Sera denemesi}

Sera denemesi 2014 yılı ilkbahar döneminde E.Ü. Ziraat Fakültesi Bahçe Bitkileri Bölümü’nde organik tarım çalışmalarının yapıldı ğı, PE örtülü-yay çaltılı $520 \mathrm{~m}^{2}$ lik seranın bir kısmında gerçekleştirilmiştir. Araştırmanın yürütüldüğü sera topraklı (kumlu killi, hafif alkali, kireçli; tuzluluğu düşük, organik maddece zengin) olup, kurulduğu andan bu yana sadece organik sebze üretim ve araştırmalarında kullanılmıştır. 
Araştırmada bitkisel materyal olarak seralarda en fazla üretilen tür olan domates (Solanum lycopersicum); çeşit olarak ise ilkbahar yetiştiriciliğine uygun bir salkım domates çeşidi olan Şimşek $F_{1}$ (Bircan Tohum, Antalya) kullanılmıştır. Domates fideleri hazır fide firmasından (Antalya Fide A.Ş, Antalya) temin edilmiş ve seraya

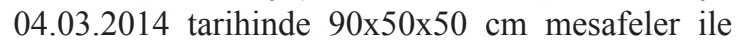
çift sıralı olarak dikilmiştir.

Araştırmada C. vulgaris'in 3 farklı uygulama şekli [I: Toprağa toz alg uygulaması $\left(2.5 \mathrm{~g} \mathrm{fide}^{-1}\right)$, II: Toprağa sıv1 alg uygulaması $\left(250 \mathrm{~mL} \mathrm{fide}{ }^{-1}\right)$, III: Yaprağa sıvı alg spreylenmesi (biyoreaktörden çıkan sıvı algin direkt kullanımı ve tüm yaprakların yıkanması şeklinde)] denenmiş ve alg uygulanmayan bitkiler IV: Kontrol grubunu oluşturmuştur. Deneme tesadüf parselleri deneme desenine göre 3 tekrarlı kurulmuş ve her tekrarda 12 bitkiye yer verilmiştir. Toprağa kuru alg uygulaması, dikim öncesi açılan dikim çukurlarına belirtilen miktarın dökülmesi ve üzerine fide dikilmesi şeklinde; sıvı alg ise fide dikiminden sonra fide köklerine belirtilen dozun dökülmesi şeklinde olmuştur. Toprağa sıvı alg uygulamasında fidelere dikim sonrası ayrıca can suyu verilmemiştir. Yapraktan spreyleme ile alg uygulamasında ise tübüler fotobiyoreaktörden çıkan alg direkt kullanılmış, alg tüm yapraklar yıkanacak şekilde fidelere püskürtülmüştür.

Bitkilerin beslenmesinde sadece sera toprağ 1 işlenirken, organik tarım yönetmeliğine uygun olarak taban gübrelemesi (50 kg da ${ }^{-1}$ Biofarm, Çamlı Yem Besicilik, Işıkkent-İzmir) yapılmış ve üretim dönemi boyunca başka gübre kullanılmamıştır. Bitkilerin sulanmasında damla sulama yöntemi kullanılmış ( $2 \mathrm{~L} \mathrm{~h}^{1}$ debiye sahip boru içine entegre damlatıcılı); sulama miktarının belirlenmesinde ise sera içerisine yerleştirilmiş Class A Pan'dan yararlanılmıştır.

Üretimde organik tarım esaslarına bağlı kalınmış; bitki bakım işleri (sardırma, koltuk alma, çapalama, budama, hastalık ve zararlı mücadelesi, hasat vs) Sevgican (2002)'a göre yürütülmüştür. Tozlaşmaya yardımcı olmak amacı ile vibratör kullanılmış; haftada 2 gün sabah erken saatlerde çiçekler sarsılmıştır. Bitki büyümesi 7 salkım üzerinden büyüme ucunun alınması şeklinde durdurulmuştur.

Yetiştirme periyodu boyunca (15.05.201430.06.2014) toplam 9 hasat yapılmış, her hasatta konusuna göre elde edilen meyvelerin ağırlıkları alınarak toplam verim $\left(\mathrm{kg} \mathrm{m}^{-2}\right)$, toplanan meyvelerin sayıları alınarak toplam meyve sayısı (adet $\mathrm{m}^{-2}$ ) belirlenmiştir. Ortalama meyve ağırlıkları (g meyve ${ }^{-1}$ ) toplam ağırlık/meyve sayısı ile hesaplanmıştır. Hasat edilen meyveler boylama halkalarından geçirilerek 4 farklı boya $(\varnothing<3.5,3.5$ $4.5,4.5-5.5, \varnothing>5.5)$ ayrılmış ve her sınıfa dahil meyvelerin oranı $\%$ olarak verilmiştir.

03.06.2014 tarihinde 3. salkımdaki kızaran meyveler hasat edildikten sonra uygulamalara ait her tekerrürden 10 adet homojen meyve seçilerek kalite analizleri yapılmıştır. Meyvelerin sertliği (N) Effegi uçlu FT011 penetrometre (Fruit Tester, Alfonsine, Italy) yardımıyla ölçülmüş; bu meyvelerin yaş ağırlıkları alınarak, $65{ }^{\circ} \mathrm{C}$ sıcaklığa ayarlı etüvde kurutulup tartılmış ve kuru ağırlıkları [KA (g)] belirlenmiş̧tir (Kacar 1972). Toplam suda çözünebilir kuru madde miktarı'nın [TSÇKM (\%)] belirlenmesi için parçalayıcı ile parçalanan meyve, kaba filtre kağıdından süzüldükten sonra 1-2 damla örnek, dijital el reflaktoremetresi (Euromex RD 645 , The Netherlands) ile okunmuş, yine süzükten alınan örneğin; $0.1 \mathrm{~N} \mathrm{NaOH}$ çözeltisi ile $\mathrm{pH}$ metre (MP220, Mettler Toledo, Schwerzenbach, Switzerland) yardımıyla titrasyonu yapılmış ve titre edilebilir asit miktarı [TA (mval $\left.\left.100 \mathrm{~mL}^{-1}\right)\right]$ harcanan $\mathrm{NaOH}$ miktarı üzerinden hesaplanmıştır (Karaçalı 1993). Süzüğe batırılan el tipi EC (Mettler ToledoMC-126, Schwerzenbach, Switzerland) metre ve masa tipi $\mathrm{pH}$ metre (Mettler Toledo-MP220, Schwerzenbach, Switzerland) probu yardımı ile meyve suyu elektriksel iletkenlik [EC $\left(\mathrm{dS} \mathrm{m}^{-1}\right)$ ] ve $\mathrm{pH}$ değerleri belirlenmiştir. Meyve vitamin $\mathrm{C}$ içeriği (mg $100 \mathrm{~mL}^{-1}$ ) oksalik asit ile stabilize edilmiş örneklerin, 2-6 diklorofenlindefenol boya maddesi ile renklendirilmesi esasına göre spektrofotometrik (Varian Cary 100 UV-Visible spektrofotometre; Varian, Inc., Polo Alto, California, USA) yöntemle belirlenmiştir (Pearson 1970). Seçilen meyvelerin rengi renkölçerle (Minolta CR-300, Japan) L 
[parlaklık (L)], a (pozitif a kırmızı, negatif a yeşil) ve $b$ (pozitif $b$ sarı, negatif $b$ mavi) üzerinden belirlenmiştir (McGuire 1992).

Üretim dönemi sonunda 23.06.2014 tarihinde her uygulamadan seçilen 2 bitkide bitki gelişim ve biyomas değerlerine bakılmıştır. Bitkiler sökülmeden toprak yüzeyinden büyüme ucuna kadar olan gövdede şerit metre yardımı ile bitki boyu (cm); dijital kumpas ile gövdenin orta yerinden gövde çap1 $(\mathrm{mm})$ ölçülmüş; daha sonra sökülen bitkilerin kök boyu ölçülmüş ve bitki kök, gövde, yaprak, salkım ve meyvelerine ayrılarak tartılıp yaş ağırlıkları, 65 ${ }^{\circ} \mathrm{C}$ sıcaklığa ayarlı etüvde kurutulup tartılarak da kuru ağırlıkları (g) belirlenmiştir (Kacar 1972).

Hasat döneminde her tekerrürden alınan genç yaprakların renkölçerle $\mathrm{L}$, a ve $\mathrm{b}$ değerleri ile a ve b değeri üzerinden hesaplanan Hue ve Kroma renk değerleri belirlenmiş, aynı yaprakların \% 80'lik aseton ile homojenize edildikten sonra spektrofotometrik yöntem ile klorofil a, klorofil b ve toplam klorofil değerleri ( $\left.\mathrm{mg} \mathrm{L}^{-1}\right)$ belirlenmiştir (Arnon 1949).

Araştırmadan elde edilen verilere, bir SPSS programı olan PAWS Statics 18 istatistiksel analiz paket programı kullanılarak varyans analizi uygulanmış ve ortalamalar arasındaki farklılıkları belirlemek için \% 5 önem düzeyinde Duncan testi yapılmıştır. Tablolarda olasılık $(P)$ değerleri verilmiştir.

\section{Bulgular ve Tartışma}

\subsection{Chlorella vulgaris üretimi ile ilgili bulgular}

Yapılan her iki üretim sonucunda tübüler fotobiyoreaktörde sıvı olarak toplam $200 \mathrm{~L}$ alg; toplam miktarın santrifüjlenmesi ile 240.2 g pasta kıvamında alg biyoması ve pastanın kurutulması ile de $58.42 \mathrm{~g}$ kuru alg elde edilmiştir.

Çoğaltılarak elde edilen $C$. vulgaris'in yapılan element analizinde içeriğinin \% $5.49 \mathrm{~N}, \% 0.72 \mathrm{~K}$, \% 5.39 Ca ve \% 0.69 Mg olduğu belirlenmiştir.

C. vulgaris alginin tübüler fotobiyoreaktörde üretimi surasinda elde edilen $\mathrm{pH} 7.2$ ile 8.1 arasında değişim göstermiştir (Şekil 2). pH'ın üretim sürecinde giderek arttığı gözlenmiş ve sisteme saf $\mathrm{CO}_{2}$ verilerek $\mathrm{pH}$ istenilen aralıkta tutulmaya çalışılmıştır. Sistemde sıcaklık iki dönemde de 21.3 ile $25.7^{\circ} \mathrm{C}$ arasında değişm göstermiştir. Üretimin sonuna doğru hücre sayısında artmalara bağlı olarak sıcaklığın da arttığı gözlenmiştir (Şekil 3). Üretim boyunca her gün yapılan hücre sayımları, C.vulgaris hücresinin I. üretimde 464 ile 2380; II. üretimde 311 ile $897 \times 10^{4}$ hücre $\mathrm{mL}^{-1}$ arasında değiştiğini göstermiştir (Şekil 4).

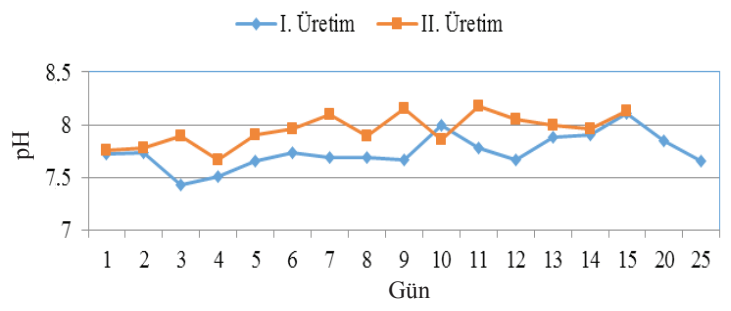

Şekil 2- Tübüler fotobiyoreaktörde $C$. vulgaris'in üretiminde $\mathbf{p H}$ 'nın değişimi

Figure 2- $p H$ changes during the production of $C$. vulgaris in tubuler photobioreactor

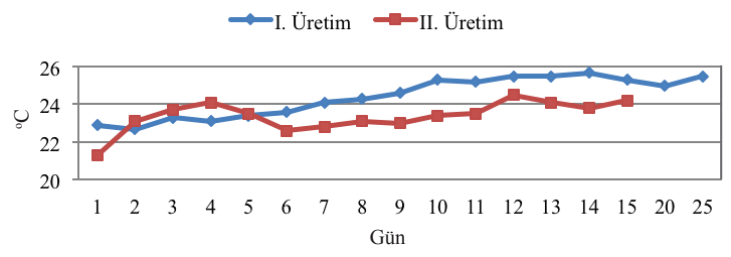

Şekil 3- Tübüler fotobiyoreaktörde $C$. vulgaris'in üretiminde sıcaklığın değişimi

Figure 3- Temperature changes during the production of C. vulgaris in tubuler photobioreactor

Yürütülen bu çalışmada C. vulgaris'ten biyogübre elde etmek üzere bir tasarım olarak oluşturulan tübüler fotobiyoreaktörün avantajları yanında akrilik borularda belirli bir günden sonra meydana gelen alg yapışmaları ve bunların temizliğindeki zorluklar gibi büyük dezavantajları da olmuştur (Naz \& Gökçek 2004). $\mathrm{Bu}$ amaçla, ilk olarak $\mathrm{HCl}$ çözeltisiyle borulardaki yapışma yok edilmeye çalışılmış; başarılı olamayınca \% 16'lık sodyum hipoklorit ile yapışma temizlenmiştir. Fakat hem kullanılan maddenin 
kimyasal olması hem de akrilik borularda aşınma ve matlaşma yapması ayrıca matlaşma nedeni ile üretilen alg hücrelerinin 1şığı eşit oranda alamaması ihtimali ile başka temizleme yöntemleri denenmiş ve en etkin yöntemin borularla aynı çapta süngerlerin sistemde döndürülerek yapılan mekanik temizleme şekli olduğu görülmüştür. Mekanik temizlemede sisteme atılan süngerin borularda ilerleyebilmesi için pompanın gücünün de bu süngeri döndürebilecek kapasitede olması ve sistemdeki boruların süngeri toplama tankına düşürebilecek şekilde tasarlanması gerekmektedir.

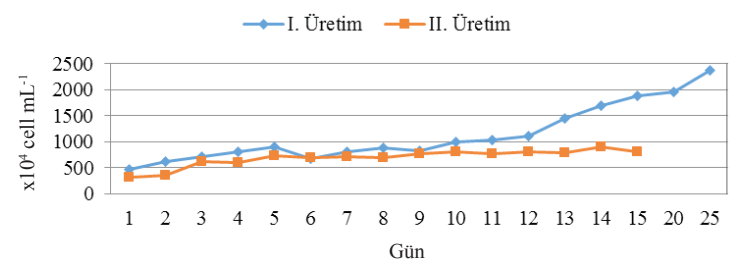

Şekil 4- Tübüler fotobiyoreaktörde $C$. vulgaris'in üretiminde hücre sayısının değişimi

Figure 4-Cell number changes during the production of C. vulgaris in tubuler photobioreactor

\subsection{Sera denemesine ait bulgular}

C. vulgaris'in farklı uygulamaları kontrole göre bitki boyu, gövde çapı ve kök boyunu artırmış ancak bu etki istatistiksel olarak $(\mathrm{P}>0.05)$ önemsiz bulunmuştur (Çizelge 1). En uzun bitki boyu ve en kalın gövde çapı toprağa sıvı alg uygulamasından; en uzun kök boyu yapraktan alg spreylenmesi uygulamasından elde edilmiştir (Çizelge 1).
Çizelge 1- Bitki boyu, gövde çapı ve kök boyu üzerine uygulamalarm etkisi

Table 1-Effects of treatments on plant height, stem diameter and root lenght

\begin{tabular}{lccc}
\hline Uygulama & $\begin{array}{c}\text { Bitki boyu } \\
(\mathrm{cm})\end{array}$ & $\begin{array}{c}\text { Gövde çapı } \\
(\mathrm{mm})\end{array}$ & $\begin{array}{c}\text { Kök boyu } \\
(\mathrm{cm})\end{array}$ \\
\hline Toprağa sıv1 & 189.7 & 15.8 & 24.9 \\
Toprağa kuru & 189.2 & 15.1 & 27.1 \\
Yaprağa sprey & 186.9 & 14.9 & 28.2 \\
Kontrol & 181.8 & 12.4 & 22.2 \\
\hline \multicolumn{1}{c}{$\mathrm{P}$} & 0.251 & 0.221 & 0.780 \\
\hline
\end{tabular}

Üretim dönemi sonunda sökülen bitki organlarına ait yaş ve kuru ağırlıklara farklı alg uygulamalarının etkileri Çizelge 2'de verilmiştir. Uygulamaların yaprak yaş ağırlığı $(\mathrm{P}=0.024)$, meyve yaş $(\mathrm{P}=0.004)$ ve kuru $(\mathrm{P}=0.000)$ ağırlığı üzerine etkisi istatistiksel olarak önemli bulunmuştur. Kontrol uygulaması ile karşılaştırıldığında toprağa kuru alg uygulaması en başarılı sonucu vermiş ve toplam bitki yaş ağırlığını $\% 32.7$, toplam bitki kuru ağırlığını \% 32.5 oranında artırmıştır. Dört ay süren yetiştiricilik süresi sonunda önceki çalışmalara benzer şekilde, uygulama şekli fark etmeksizin tüm bitkilerin gelişiminin kontrol bitkilerinden daha fazla olduğu belirlenmiştir (Kumbul 2000).

Uygulamaların toplam verim, toplam meyve adedi ve ortalama meyve ağırlığı üzerine etkisi önemli bulunurken, meyve sinfflandırması üzerine etkisi önemsiz bulunmuştur. Alg uygulamaları verim değerlerini artırmış; toplam verim değerleri $15.11-10.22 \mathrm{~kg} \mathrm{~m}^{-2}$ arasında değişmiş ve en yüksek toplam verim toprağa kuru alg uygulamasindan elde edilmiştir (Çizelge 3). Kontrol uygulaması ile

\section{Çizelge 2- Bitki organlarına ait biyomas değerleri (g) üzerine uygulamaların etkisi}

Table 2-Effects of treatments on biomass of plant tissue (g)

\begin{tabular}{|c|c|c|c|c|c|c|c|c|c|c|}
\hline \multirow{2}{*}{ Uygulama } & \multicolumn{2}{|c|}{ Yaprak } & \multicolumn{2}{|c|}{ Gövde } & \multicolumn{2}{|c|}{ Salkım } & \multicolumn{2}{|c|}{ Meyve } & \multicolumn{2}{|c|}{$K \ddot{o k}$} \\
\hline & $Y A$ & $K A$ & $Y A$ & $K A$ & $Y A$ & $K A$ & $Y A$ & $K A$ & $Y A$ & $K A$ \\
\hline Toprağa sıvı & $733.5 \mathrm{a}$ & 148.1 & 291.4 & 56.4 & 44.7 & 11.8 & $3670.7 \mathrm{~b}$ & $256.7 \mathrm{~b}$ & 25.5 & 6.2 \\
\hline Toprağa kuru & $781.0 \mathrm{a}$ & 161.9 & 357.9 & 65.8 & 66.9 & 15.8 & $4231.9 \mathrm{a}$ & $291.5 \mathrm{a}$ & 34.8 & 8.6 \\
\hline Yaprağa sprey & $680.5 \mathrm{a}$ & 134.5 & 255.8 & 50.4 & 47.3 & 11.9 & $3494.6 \mathrm{~b}$ & $261.9 \mathrm{~b}$ & 34.3 & 8.3 \\
\hline Kontrol & $501.2 \mathrm{~b}$ & 111.8 & 254.2 & 49.7 & 42.0 & 9.9 & $2863.6 \mathrm{c}$ & $189.2 \mathrm{c}$ & 23.6 & 6.5 \\
\hline $\mathrm{P}$ & 0.024 & 0.139 & 0.326 & 0.430 & 0.132 & 0.118 & 0.004 & 0.000 & 0.406 & 0.398 \\
\hline
\end{tabular}

YA, yaş ağırlık; KA, kuru ağırlık 
karşılaştırıldığında toplam verim toprağa sıvı, toprağa kuru ve yaprağa sprey uygulamalarında sirasiyla \% 21.9, 32.4, 18.1 oranında artış göstermiştir. Toplam meyve adedi 32.4 ile 24.2 adet $\mathrm{m}^{-2}$ arasında; ortalama meyve ağırlığı 135.2 ile $118.9 \mathrm{~g}$ arasında değişm göstermiş; en yüksek değerler alg uygulamalarından elde edilmiştir. Toprağa sıvı alg uygulamasında ortalama meyve ağırlığının düşük ancak toplam meyve adedinin yüksek olduğu görülmüştür. Meyve sinıflandırılmasında çapı $5.5 \mathrm{~cm}$ 'den büyük 1 . boy meyveler en fazla $\% 78.4$ ve $\% 77.4$ ile toprağa sıvı ve kuru alg uygulaması yapılan bitkilerden, çapı $3.5 \mathrm{~cm}$ 'den küçük olan 4 . boy meyveler ise en fazla $\% 4.5$ ile kontrol grubundaki bitkilerden; en az ise \% 0.6 ile toprağa kuru alg uygulaması yapılan bitkilerden alınmıştır (Çizelge 3).

Verim değerleri kullanılan çeşide, iklim koşullarına, üretim sistemine, yetiştirme periyodu gibi etkenlere bağlı olarak değișebilmektedir. Genel olarak serada konvansiyonel çift ürün (kısa dönem) yetiştiriciliğinde domates veriminin 8 ile $13 \mathrm{~kg}$ $\mathrm{m}^{-2}$ arasında değiştiği belirtilmiştir (Greer \& Diver 2000; Sevgican 2002). Yürütülen bu çalışmada verim değerleri 10.22 (kontrol) ile 15.11 (topraktan kuru alg uygulaması) $\mathrm{kg} \mathrm{m}^{-2}$ arasında değişmiş ve serada organik tarım esaslarına göre yürütülen çalışmalardan elde edilen verim değerlerine benzer sonuçlar vermiştir (Tüzel et al 2001; 2003). Özellikle alg kullanılan uygulamalarda verim değerleri hem kontrol uygulamasina göre hem de olması gereken sınır değerlerden yüksek bulunmuş; ayrıca birinci sınıf meyve adedi fazlalaşmıştır. Ayrıca ilk hasatta kontrol grubuna ait bitkilerden sadece 1 adet meyve hasat edilirken; alg uygulamaların yapıldığı bitkilerde toplam 14 adet kızarmış meyve hasat edilmiştir. $\mathrm{Bu}$ da $C$. vulgaris'in biyogübre olarak uygulanmasının domates bitkilerinde meyve oluşumunda erkencilik de gösterdiğini ortaya koymuştur. Elde ettiğimiz bu sonuçlar sağliklı ve bilinçli beslenme yanında çevreci yaklaşımların önemsendiği günümüz koşullarında konvansiyonel üretime yakın ve/veya fazla verim elde edilmesini sağlayan alg kullanımının kimyasal gübrelemeye alternatif olarak kullanılabileceğini göstermektedir.

Mikroalgler salgıladıkları şelatlar sayesinde ortamdaki besin maddelerinden bitkinin daha iyi faydalanmasına; ürettikleri organik maddeler veya ölen alglerin ayrışarak sağladığ 1 inorganik maddelerle yine bitkilerin beslenmesine artı katkıda bulunmaktadır. Ayrıca mikroalglerin ürettikleri bir takım enzimler ve hormonların bitki büyüme ve gelişmesi ile verimi arttırmada etkili olduğu bilinmektedir (Ergün et al 2010). Yürütülen çalışmada alg uygulaması ile kontrol bitkilerine göre daha yüksek verim ve bitki gelişimi elde edilmiştir. Benzer sonuçlar C. vulgaris'in biyogübre olarak kullanıldığ 1 marulda (Article 2008) ve üzümde (Abd \& Moniem 2008) yapılan çalışmalarda da belirtilmiştir. Elde ettiğimiz bu sonuçların $C$. vulgaris'in sahip olduğu ve yetiştirilen bitkiye aktardığ 1 yüksek protein içeriğinden kaynaklandığ 1 düşünülmektedir. Farklı formlarda uygulanan $C$. vulgaris'den verim ve bitki gelişimi açısından en iyi sonuç toprağa yapılan kuru alg uygulamasından elde edilmiştir. Kuru alg uygulaması dikim çukurlarına doğrudan algin verilmesi şeklinde yapılmış; algin uygulanan su ile zamana bağlı olarak çözünmesi ve toprakta yavaş salınımına bağlı olarak çözünen

Çizelge 3- Uygulamalarının verim değerleri üzerine etkileri

Table 3-Effects of treatments on plant yield parameters

\begin{tabular}{|c|c|c|c|c|c|c|c|}
\hline \multirow[b]{2}{*}{ Uygulama } & \multirow{2}{*}{$\begin{array}{c}\text { Toplam } \\
\text { verim } \\
\left(\mathrm{kg} \mathrm{m}^{-2}\right)\end{array}$} & \multirow{2}{*}{$\begin{array}{c}\text { Toplam meyve } \\
\text { adedi } \\
\left(\text { adet } \mathrm{m}^{-2}\right)\end{array}$} & \multirow{2}{*}{ 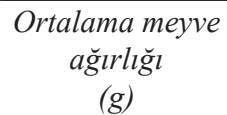 } & \multicolumn{4}{|c|}{ Meyve siniflandirmast (\%) } \\
\hline & & & & $<3.5 \mathrm{~cm}$ & $3.5-4.5 \mathrm{~cm}$ & $4.5-5.5 \mathrm{~cm}$ & $>5.5 \mathrm{~cm}$ \\
\hline Toprağa sıv1 & $13.10 \mathrm{~b}$ & $32.4 \mathrm{a}$ & $113.7 \mathrm{~b}$ & 2.2 & 2.7 & 16.7 & 78.5 \\
\hline Toprağa kuru & $15.11 \mathrm{a}$ & $31.3 \mathrm{a}$ & $135.2 \mathrm{a}$ & 0.6 & 5.6 & 16.3 & 77.5 \\
\hline Yaprağa sprey & $12.48 \mathrm{~b}$ & $27.5 \mathrm{ab}$ & $127.1 \mathrm{ab}$ & 2.9 & 6.5 & 15.5 & 75.0 \\
\hline Kontrol & $10.22 \mathrm{c}$ & $24.2 \mathrm{~b}$ & $118.9 \mathrm{ab}$ & 4.5 & 9.8 & 15.4 & 70.3 \\
\hline $\mathrm{P}$ & 0.004 & 0.049 & 0.042 & 0.165 & 0.309 & 0.990 & 0.564 \\
\hline
\end{tabular}


bileşiklerinin bitki tarafindan daha fazla absorbe edilmesi nedeni ile bitki gelişimi ve verimi arttırdığı düşünülmektedir.

Yapılan üç farklı alg uygulamasının KA, sertlik, meyve suyu EC ve pH değeri, TSÇKM, TA, renk ile Vitamin C içeriği üzerinde kısmi artış göstermesine rağmen bu artış istatistiksel olarak önemsiz bulunmuştur (Çizelge 4).

Farklı alg uygulamalarının genç domates yapraklarında hue renk değeri hariç diğer renk parametreleri üzerine etkisi $(\mathrm{P} \leq 0.05)$ ve ayn yapraklarda belirlenen klorofil $a$, klorofil $b$ ve toplam klorofil değerleri üzerine etkisi $(\mathrm{P}=0.000)$ önemli bulunmuştur. Yüksek $\mathrm{L}, \mathrm{b}$ ve chroma; düşük a ve hue değeri ile yaprağa spreylenen alg uygulaması diğer uygulama ve kontrol bitkilerine göre en parlak ve en koyu doygun yeşil renge sahip olmuştur. Benzer şekilde en yüksek klorofil a, b ve toplam klorofil içeriği ile yaprağa spreylenen alg uygulamasına sahip bitkilerden elde edilmiştir. Bunu toprağa sıvı alg uygulaması izlemiş, kontrol ve toprağa kuru alg uygulaması aynı istatistiksel grupta yer almakla birlikte en düşük klorofil içeriklerine sahip olmuşlardır (Çizelge 5).

Fotosentez metabolizması üzerinde etkili bir pigment olan klorofilin en yüksek miktarı yapraktan alg spreylemesi uygulamasından elde edilmiş; kontrol grubuna oranla klorofil a miktarı \% 59.5, klorofil b miktarı \% 86.7 ve toplam klorofil miktarı \% 74.8 oranında artış göstermiştir. Elde edilen bu sonuçlar yapraklara uygulanan $C$. vulgaris alginin bitki yapraklarında fotosentezi arttırdığının bir göstergesi olmuştur. Whapham et al (1993) tarafından yapılan benzer bir çalışmada da en koyu yeşil yaprağa sahip bitkilerin yapraktan alg uygulanan bitkiler olduğu belirtilmiştir.

\section{Sonuçlar}

Elde edilen sonuçlar genel olarak değerlendirildiğinde; üretilen C. vulgaris alginin bitki gelişimi ve verimi teşvik ettiği, bazı meyve kalite parametrelerini de arttırdığ 1 görülmüştür. Çalışmada kullanılan

\section{Çizelge 4- Uygulamaların bazı meyve kalite parametreleri üzerine etkisi}

Table 4- Effects of treatments on some fruit quality parameters

\begin{tabular}{|c|c|c|c|c|c|c|c|c|c|c|}
\hline Uygulama & $\begin{array}{l}K A \\
(\%)\end{array}$ & $\begin{array}{c}\text { Sertlik } \\
(N)\end{array}$ & $\begin{array}{c}E C \\
\left(d S m^{-1}\right)\end{array}$ & $p H$ & $\begin{array}{c}\text { TSÇKM } \\
(\%)\end{array}$ & $\begin{array}{c}T A \\
(m v a l 100 \\
\left.m L^{-1}\right)\end{array}$ & $L$ & $\begin{array}{c}\text { RENK } \\
a\end{array}$ & $b$ & $\begin{array}{c}\text { Vitamin } C \\
(m g 100 \\
\left.m L^{-1}\right)\end{array}$ \\
\hline Toprağa sıvı & 6.53 & 40.2 & 4.6 & 4.5 & 5.3 & 6.0 & 40.48 & 22.69 & 26.93 & 14.0 \\
\hline Toprağa kuru & 6.01 & 39.9 & 5.0 & 4.6 & 4.5 & 5.6 & 40.84 & 21.75 & 26.55 & 15.0 \\
\hline Yaprağa sprey & 6.53 & 43.0 & 5.1 & 4.6 & 5.2 & 5.6 & 39.32 & 23.14 & 25.96 & 14.2 \\
\hline Kontrol & 5.94 & 40.1 & 4.9 & 4.6 & 4.8 & 5.3 & 40.83 & 22.10 & 26.72 & 12.0 \\
\hline $\mathrm{P}$ & 0.113 & 0.137 & 0.350 & 0.240 & 0.366 & 0.089 & 0.431 & 0.382 & 0.815 & 0.499 \\
\hline
\end{tabular}

Çizelge 5- Yaprak renk değerleri ile klorofil (a, b ve toplam) içeriği üzerine uygulamaların etkisi

Table 5- Effects of treatments on leaf color and chlorophyll ( $a, b$ and total) content

\begin{tabular}{|c|c|c|c|c|c|c|c|c|}
\hline \multirow{2}{*}{ Uygulama } & \multicolumn{5}{|c|}{ Renk } & \multicolumn{3}{|c|}{ Klorofil $\left(m g L^{-1}\right)$} \\
\hline & $L$ & $a$ & $b$ & Ние & Chroma & $a$ & $b$ & Toplam \\
\hline Toprağa s1v1 & $40.83 \mathrm{c}$ & $-10.46 \mathrm{a}$ & $15.17 \mathrm{c}$ & 124.59 & $18.43 \mathrm{a}$ & $7.76 \mathrm{~b}$ & $2.56 \mathrm{~b}$ & $10.31 \mathrm{~b}$ \\
\hline Toprağa kuru & $44.08 \mathrm{bc}$ & $-12.83 b$ & $19.94 \mathrm{~b}$ & 122.76 & $23.71 \mathrm{~b}$ & $5.01 \mathrm{c}$ & $1.81 \mathrm{~b}$ & $6.82 \mathrm{c}$ \\
\hline Yaprağa sprey & $47.75 \mathrm{a}$ & $-15.38 \mathrm{c}$ & $25.79 \mathrm{a}$ & 120.82 & $30.03 \mathrm{c}$ & $12.61 \mathrm{a}$ & $16.02 \mathrm{a}$ & $28.62 \mathrm{a}$ \\
\hline Kontrol & $44.75 \mathrm{ab}$ & $-13.82 b c$ & $21.30 \mathrm{~b}$ & 123.07 & $25.39 \mathrm{~b}$ & $5.11 \mathrm{c}$ & $2.10 \mathrm{~b}$ & $7.21 \mathrm{c}$ \\
\hline $\mathrm{P}$ & 0.022 & 0.006 & 0.011 & 0.197 & 0.008 & 0.000 & 0.000 & 0.000 \\
\hline
\end{tabular}


biyogübrenin domates dışında diğer türlerde de kullanıldığında olumlu sonuçlar elde edileceği beklenmektedir.

Denemeye alınan uygulamalar içerisinde toprağa yapılan uygulamaların (özellikle kuru alg uygulamasının) daha olumlu sonuçlar verdiği görülmüştür. Elde edilen umutvar sonuçlar dahilinde farklı doz ve uygulama şekli ile araştırmaların devam ettirilmesi gerekmektedir.

Üretim boyunca yaşanan sorunlar tübüler sistemlerin modifiye edilerek daha iyi tasarımla kullanılmasını ve bununla beraber üretimde daha fazla artış sağlanabileceğini göstermektedir.

Tarımda fazlaca kullanılan bir çok kimyasal içerikli gübre yeraltı ve yer üstü su kaynaklarında kirliliğe ve toprakta tuzlanmaya sebep olarak tarımsal üretimi kısıtlamaktadır. Yürütülen bu çalışmada kullanılan mikroalg tamamen biyolojik olup, çevreye zarar vermeden biyogübre olarak kullanılabilmektedir. Organik gübre çeşitliliğinin sınırlı olduğu organik tarımda da alternatif bir gübre olarak kullanımı önerilmektedir.

\section{Teșekkür}

$\mathrm{Bu}$ çalışma Ege Üniversitesi Bilimsel Araştırma Projeleri "2014 FEN 005" no'lu proje kapsamında desteklenmiştir.

\section{Kaynaklar}

Abd E A \& Moniem E (2008). Effect of green alga cells extract as foliar spray on vegetative growth, yield and berries quality of superior grapevines. AmericanEurasian Journal of Agricultural \& Environmental Sciences 4(4): 427-433

Abetz P (1980). Seaweed extracts: Have they a place in Australian agriculture or horticulture? Journal of the Australian Institute of Agricultural Science 46: 23-29

Arnon D I (1949). Copper enzymes in isolated chloroplasts. Polyphenoloxidase in Beta vulgaris. Plant Physiology 24(1): 1-15

Article F L (2008). Effect of Chlorella vulgaris as biofertilizer on growth parameters and metabolic aspects of lettuce plant. Journal of Agriculture \& Social Sciences 4: 165-169
Cirik S \& Gökpınar Ş (1993). Plankton Bilgisi ve Kültürü. Ege Üniversitesi Su Ürünleri Fakültesi Yayınları: 47, İzmir

Ergün O, Daşgan Y H \& Işık O (2010). Su kültüründe yetiştirilen kıvırcık marul bitkisinde mikroalg (Chlorella vulgaris) uygulamasinın etkileri. 9. Ulusal Sebze Tarımı Sempozyumu, Bildiriler: 12-14 Eylül 2012, Konya, s. 330-334

Greer L \& Diver S (2000). Organic Greenhouse Vegetable Production: Horticulture Production Guide. Fayetteville: Appropriate Technology Transfer for Rural Areas (ATTRA), pp. 31, AR, USA

Guillard R R L (1973). Division rates. In: Stein, J.R. (Ed.), Handbook of Phycological Methods-Culture Methods and Growth Measurements. Cambridge University Press, Cambridge, 289-311 pp

Güner H \& Aysel V (1996). Marine Benthic Vegetation, Chapter 18. Ecological studies Vol. 123, Schramm/ Nienhuis (eds) Springer-Verlag Berlin Heidelberg, 421-432 pp.

Hekimoğlu B \& Altındeğer M (2006). Organik Tarım ve Bitki Koruma Açısından Organik Tarımda Kullanılacak Yöntemler, Samsun Valiliği Gıda Tarım ve Hayvancılık İl Müdürlüğü, Samsun, 200 s

Kacar B (1972). Bitki ve Toprağın Kimyasal Analizleri. II. Bitki Analizleri. Ankara Üniversitesi Ziraat Fakültesi Yayınları, 642 s, Ankara

Karaçalı İ (1993). Bahçe Ürünlerinin Muhafaza ve Pazarlanmas1. Ege Üniversitesi Ziraat Fakültesi Yayınları: 494, İzmir

Kumbul B (2000). Deniz yosunlarının bahçe bitkilerinde kullanım alanları. Yüksek lisans tezi, Akdeniz Üniversitesi Fen Bilimleri Enstitüsü (Basılmamış), Antalya

McGuire G R (1992). Reporting of objective color measurements. HortScience 27(12): 1254-1255

Naz M \& Gökçek K (2004). Fotobiyoreaktörler: Fototropik mikroorganizmalar için alternatif üretim sistemleri. Ulusal Su Günleri: 6-8 Ekim, İzmir, s. 545-551

Pearson D (1970). The Chemical Analysis of Food. Auxil, London

Safi C, Zebib B, Merah O, Pontalier P Y \& Vaca-Garcia C (2014). Morphology, composition, production, processing and applications of Chlorella vulgaris: A review. Renewable and Sustainable Energy Reviews 35: $265-278$ 
Selvam G G \& Sivakumar K (2014). Influence of seaweed extract as an organic fertilizer on the growth and yield of Arachis hypogea L. and their elemental composition using SEM-energy dispersive spectroscopic analysis. Asian Pacific Journal of Reproduction 3(1): 18-22

Sevgican A (2002). Örtüaltı Sebzeciliği. Cilt I (Topraklı Tarım). Ege Üniversitesi Ziraat Fakültesi Yayınları: 528, İzmir

Sivasankari S, Venkatesalu V, Anantharaj M \& Chandrasekaran M (2006). Effect of seaweed extracts on the growth and biochemical constituents of Vigna sinensis. Bioresource Technology 97(14): 1745-1751

Sukatar A (2002). Alg Kültür Yöntemleri. Ege Üniversitesi Fen Fakültesi Yayınları: 184, İzmir

Şimşek Z (1995). Klemantin mandarinde bilezik alma, demir bileşikleri ve deniz yosunu özü uygulamalarının verim ve kalite üzerine etkileri. Yüksek lisans tezi, Akdeniz Üniversitesi Fen Bilimleri Enstitüsü (Basılmamış), Antalya

Tüzel Y, Tuncay Ö, Anaç D \& Tüzel İ H (2001). Effects of different organic fertilizers and irrigation levels on yield and quality of organically grown greenhouse tomatoes. Organic Agriculture in the Mediterranean Basin 285-298 pp

Tüzel Y, Yağmur B \& Gümüş M (2003). Organic tomato production under greenhouse conditions. Acta Horticulture 614: 775-780

Whapham C A, Blunden G, Jenkins T \& Hankins S D (1993). Significance of betaines in the increased chlorophyll content of plants treated with seaweed extract. Journal of Applied Phycology 5: 231-234

Whapham C A, Jenkins T, Blunden G \& Hankins S D (1994). The role of seaweed extracts, Ascophyllum nodusum, in the reduction in fecundity of Meloidogyne javanica. Fundamental and Applied Nematology 17(2): 181-183

Zheng H, Yin J, Gao Z, Huang H, Ji X \& Dou C (2011). Disruption of Chlorella vulgaris cells for the release of biodiesel-producing lipids: A comparison of grinding, ultrasonication, bead milling, enzymatic lysis, and microwaves. Applied Biochemistry and Biotechnology 164(7): 1215-1224 